\title{
Performance and carcass traits of Nellore and Red Norte steers finished in feedlot
}

\section{Otávio Rodrigues Machado Neto ${ }^{1}$, Márcio Machado Ladeira ${ }^{2}$, Tarcisio de Moraes Gonçalves ${ }^{3}$, Leandro Sâmia Lopes ${ }^{1}$, Dalton Mendes de Oliveira ${ }^{1}$, Renato Ribeiro de Lima ${ }^{4}$}

\footnotetext{
1 Doutorando do Programa de Pós Graduação em Zootecnia da UFLA. Bolsista de Doutorado do CNPq.

2 Departamento de Zootecnia da Universidade Federal de Lavras. Pesquisador do INCT-Ciência Animal.

${ }^{3}$ Departamento de Zootecnia da Universidade Federal de Lavras. Pesquisador do CNPq.

${ }^{4}$ Departamento de Ciências Exatas da Universidade Federal de Lavras.
}

\begin{abstract}
The objective of this work was to evaluate average daily gain (ADG) and carcass traits in Nellore and Red Norte steers, finished in feedlots and to evaluate performance predictions by using the systems BR-CORTE, CNCPS 5.0 and NRC (2000). It was used 41 steers: 19 Nelore animals with initial body weight of $361 \pm 31 \mathrm{~kg}$ and 22 Red Norte animals with initial body weight of $367 \pm 30 \mathrm{~kg}$. Adaptation period lasted 28 days. Animal performance evaluation was composed of three 28 day period, totaling 84 days. At the end of each period, animals were weighed after a 16-hour feeding fast. Average gain weight of Red Norte steers was greater than Nellore breed animals (1.43 vs. $1.81 \mathrm{~kg} /$ day, respectively). Red Norte animals also presented greater loin eye area $\left(75.41 \mathrm{~cm}^{2}\right.$ vs. $\left.68.67 \mathrm{~cm}^{2}\right)$. It was not observed any differences on subcutaneous fat thickness and on rump fat among the genetic groups. None of the nutritional requirement system evaluated were efficient in predicting animal performance. For Nellore breed, daily average gain observed was $1.53 \mathrm{~kg} / \mathrm{day}$, with values of $1.53,1.70$ and $1.82 \mathrm{~kg} / \mathrm{day}$ predicted by NRC, CNCPS and BR-CORTE systems. Although average values and predicted by NRC were similar, according to the regression equation, intercept and inclination were different from zero and one. For Red Norte breed, performance observed was $1.88 \mathrm{~kg}$ /day with values of 1.50, 1.66 and 1.72 predicted by the systems NRC, CNCPS and BR-CORTE, probably because database of those systems is based mainly on results obtained from Angus bovines.
\end{abstract}

Key Words: composite breeds, markers, nutritional requirements, prediction equations, zebu cattle

\section{Desempenho e características de carcaça de novilhos das raças Nelore e Red Norte terminados em confinamento}

\begin{abstract}
RESUMO - Objetivou-se avaliar o ganho médio diário (GMD) e as características de carcaça em novilhos das raças Nelore e Red Norte, não-castrados, terminados em confinamento e avaliar as predições do desempenho pelos sistemas CNCPS 5.0, NRC (2000) e BR-CORTE. Utilizaram-se 41 novilhos: 19 do grupo Nelore com peso vivo inicial de $361 \pm 31$ kg e 22 do grupo Red Norte com peso vivo inicial de $367 \pm 30 \mathrm{~kg}$. O período de adaptação teve duração de 28 dias. A avaliação do desempenho animal foi composta de três períodos de 28 dias, totalizando 84 dias. Ao final de cada período, realizou-se a pesagem dos animais após jejum alimentar de 16 horas. Na raça Red Norte, o ganho médio diário foi superior ao da raça Nelore (1,81 vs. 1,43 kg/dia). Os animais da raça Red Norte apresentaram também maior área de olho-de-lombo $\left(75,41 \mathrm{~cm}^{2}\right.$ vs. $\left.68,67 \mathrm{~cm}^{2}\right)$. Não foi observada diferença nas espessuras de gordura subcutânea e de gordura na garupa entre os grupos genéticos. Nenhum dos sistemas de exigências nutricionais avaliados foram eficientes para a predição do desempenho animal. Na raça Nelore, o ganho médio diário observado foi de 1,53 kg/dia, com valores preditos de 1,53; 1,70 e 1,82 kg/dia pelos sistemas NRC, CNCPS e BR-CORTE. Apesar de os valores médio e preditos pelo sistema NRC terem sido semelhantes, de acordo com a equação de regressão, o intercepto e a inclinação foram diferentes de zero e um. Na raça Red Norte, o desempenho observado foi de 1,88 kg/dia com valores preditos de 1,50; 1,66 e 1,72 kg/dia pelos sistemas NRC, CNCPS e BR-CORTE, provavelmente porque o banco de dados desses sistemas é baseado principalmente em resultados obtidos em bovinos Angus.
\end{abstract}

Palavras-chave: equações de predição, exigências nutricionais, indicadores, raças compostas, zebuínos

\section{Introduction}

The practice of using feedlot should be understood as a management tool which helps all the rearing systems (rearing, fattening and finishing) and pasture management, partially overcoming some of the difficulties associated to the seasonality of forage production (Lanna \& Almeida, 2005). According to Siqueira et al. (2007), keeping the same 
number of animals on pasture during the dry period requires at least twice as much the area used during the rainy season.

One of the important factors to be considered when using a feedlot is the genetic group to be used, because there are sharp differences in performance among breeds and in the carcass and meat quality (Restle et al., 2000). Thus, the use of crossing as a component of the production system could lead to improvements in production efficiency and the quality of beef meat produced in Brazil.

Nellore breed herd is the largest breed reared by the Brazilian beef cattle industry and it is frequently used in different industrial crossing systems. The Red Norte breed derives from the crossing involving four breeds: Nellore or Tabapuã, Red Angus and the two final crosses are with Santa Gertrudes, Senepol or Caracu, in different orders. The objective of using this crossing scheme is to maintain high heterosis levels in the successive generations, in addition to complementariness when genetically different breeds are crossed.

According to Alencar (2004), the superiority of European $\times$ Zebu crossbred animals compared to Zebu animals should be reassessed in the various management situations because, in recent years, important genetic improvement has been observed in the beef cattle in Brazil, especially in the Zebu breeds.

The use of systems that predict animal performance has great practical importance, because once weight gain has been properly predicted, the number of days needed to reach a determined slaughter weight can be planned, avoiding unnecessary feeding of the herd or feeding for an insufficient period of time, which can occur if the systems are able to correctly predict performance in terms of weight gain.

Thus, the objective of this study was to assess the performance and carcass characteristics of Nellore and Red Norte steer finished in a feedlot. Performance predictions were assessed by using NRC (2000), CNCPS 5.0 (Fox et al., 1992) and BR-CORTE (Valadares Filho, 2006b) systems.

\section{Material and Methods}

It was used 41 intact steers at an average initial age of 20 months, from two genetic groups: 19 from the Nellore breed steers with $361 \pm 31 \mathrm{~kg}$ of initial body weight and 22 Red Norte steers with $367 \pm 30 \mathrm{~kg}$ initial body weight. The animals were placed in collective stalls with an area of $30 \mathrm{~m}^{2}$ per animal, grouped according to the genetic group. The feedlot facilities had a compacted earth floor, concrete area near the feeding trough and they were divided by smooth wire fences. The collective drinking fountains were located on the division between two stalls and vinilona feeding troughs were used, placed transversely on the upper part of the fence with $70 \mathrm{~cm}$ for each animal.

At the beginning of the adaptation period, which lasted 28 days, the animals were weighed after 16-hour fast and treated for ecto and endoparasites. They were fed the same diet ad libitum during the adaptation period as during the experimental period.

The experimental period consisted of three 28-day periods, totaling 84 days, and at the end of each period the animals were weighed also after 16-hour fast.

The diet was balanced to meet the requirements according to the NRC (2000; Table 1) and it was supplied freely in the form of complete diet at 8:00 a.m. and 3:00 p.m. and the food scraps were collected the following morning. The quantity of diet supplied was adjusted each day to allow $5 \%$ of food scraps.

Every 14 days, samples of the concentrate ingredients and silage were collected. These samples formed a composite sample which was, after pre-drying in a forced ventilation chamber at $65^{\circ} \mathrm{C}$ for 72 hours, ground in a grinder with $1-\mathrm{mm}$ mesh. Dry matter (DM), organic matter (OM), crude protein (CP), ether extract (EE), neutral detergent fiber corrected for ash and protein $\left(\mathrm{NDF}_{\mathrm{ap}}\right)$ and acid detergent fiber (ADF) were analyzed according to methodology reported by Silva \& Queiroz (2002; Table 2).

The protein and carbohydrate fractions used by the CNCPS 5.0 system were obtained from the databank of the Tabela Brasileira de Composição de Alimentos para Bovinos (Valadares Filho et al., 2006b).

Table 1 - Composition of the experimental diet

\begin{tabular}{lc}
\hline Ingredient & Composition (\%DM) \\
\hline Corn silage & 50.0 \\
Ground corn & 23.0 \\
Citrus pulp & 11.5 \\
Soybean meal & 10.0 \\
Cottonseed meal & 3.4 \\
Urea & 0.5 \\
Mineral nucleus* & 1.6 \\
& \\
Nutrients & 47.7 \\
Dry matter (\% natural matter) & 14.3 \\
Crude protein (\%DM) & 30.1 \\
Neutral detergent fiber (NDFcp) (\%DM) & 47.9 \\
Non-fibrous carbohydrate (\%DM) & 3.0 \\
Ether extract (\%DM) & 70.3 \\
Total digestible nutrients (\%MS) ${ }^{1}$ & \\
* Calcium - 235 g; phosphorus - 45 g; sulfur - 23 g; sodium - 80.18 g; zinc - 2.38 mg; \\
copper - 625 mg; iron - 1.18 mg; manganese 312 mg: cobalt - 32 mg; iodine - \\
41.6 mg; selenium - 11.25 mg; A vit. - 70.000 UI; D3 vit. - 5.000 UI; E vit. - \\
15 UI; niacin - 3.33 mg.
\end{tabular}

R. Bras. Zootec., v.40, n.5, p.1080-1087, 2011 
Table 2 - Chemical composition of the ingredients of the experimental diet

\begin{tabular}{|c|c|c|c|c|c|}
\hline Nutrient & Corn silage & Ground corn & Citrus pulp & Soybean meal & Cottonseed meal \\
\hline Dry matter (\% NM) & 34.46 & 88.66 & 90.05 & 87.26 & 87.84 \\
\hline Organic matter (\% DM) & 31.01 & 87.57 & 84.29 & 80.87 & 83.18 \\
\hline Crude protein (\% DM) & 7.88 & 8.31 & 7.53 & 46.20 & 28.73 \\
\hline Neutral detergent fiber corrected for protein and ash (\% DM) & 46.8 & 10.29 & 18.26 & 12.11 & 31.13 \\
\hline Non-fibrous carbohydrates (\% DM) & 38.32 & 77.50 & 64.77 & 32.60 & 34.21 \\
\hline Ether extract (\% DM) & 3.55 & 2.81 & 3.68 & 2.70 & 1.27 \\
\hline
\end{tabular}

Non-fibrous carbohydrates (NFC) were calculated by difference, as reported by Sniffen et al. (1992).

The information for carcass traits was obtained by using the Aloka 500V ultrasonography equipment (Corometrics Medical System, Wallingford, CT), with a 3.5 MHz linear transductor. Rib eye area (Longuissimus dorsi) and fat thickness were measured between the $12^{\text {th }}$ and $13^{\text {th }}$ ribs. Fat thickness over the Biceps femoris muscle (FTBF) was measured at the junction of the biceps femoris and gluteus medium muscles.

The images were digitalized by the Image-J software (National Institutes of Health, USA) and stored by an image capture system (Blackbos, Biotronics, Ames, IA, USA).

The periods for the assessment of the NRC (2000), CNCPS 5.0 and BR-CORTE systems lasted 56 days, which corresponded to the first two experimental periods. This occurred because the individual intake was measured in the first and second experimental periods.

The LIPE ${ }^{\circledR}$ marker was used to estimate the fecal production with the dose of one $0.5 \mathrm{~g}$ capsule/animal/day (Saliba, 2005), on days 24, 25 and 26 of the first and second experimental periods.

The concentrate intake was determined by using chromic oxide mixed in the concentrate at the proportion of $10 \mathrm{~g}$ animals/day and supplied to the animals from the $19^{\text {th }}$ to the $27^{\text {th }}$ day of the first two experimental periods. The indigestible dry matter was used for roughage intake obtained after 240 hours of ruminal incubation, according to the technique described by Casali et al. (2008). The intake was calculated according to Valadares Filho et al. (2006b).

To enter the data for each animal in the NRC (2000) and CNCPS 5.0 systems, the weight at maturity of $540 \mathrm{~kg}$ was adopted for the animals of the Nellore breed and $600 \mathrm{~kg}$ for the Red Norte animals. For both of them, the body condition stipulated was five on a scale from one to nine, at $25^{\circ} \mathrm{C}$ ambient temperature and $50 \%$ relative air humidity. Because Senepol and Caracu breeds were not used in these systems, the breeds used as components of the Red Norte composite were Red Angus, Nelore and Santa Gertrudes. Although the Red Norte group was formed from four breeds, the NRC (2000) and CNCPS 5.0 systems accept only three breeds to make predictions.

According to the data supplied to the systems for the diet ingested and animals, individual weight gain was predicted in function of the metabolizable energy and the available metabolizable protein by specific softwares. For the BR-CORTE system, the equations used were shown in the publication, which were inserted in an electronic spreadsheet software because no specific tool is available for this system.

The statistical analyses for the performance variable and the carcass characteristics were performed by using the $\mathrm{F}$ test of the GLM procedure of the SAS statistical software (1999).

The precision of the mean daily weight gain estimates by the nutritional requirements systems was analyzed by fitting a simple linear regression model of observed values (dependent variable) over predicted values (independent variable) and the statistical tests were carried out following the following hypotheses (Mayer et al., 1994): $\mathrm{H}_{0}: \beta_{0}=0$ and $\beta_{1}=1 \mathrm{X} \mathrm{H}_{\mathrm{a}}$ : naoH $_{0}$

The predicted values were plotted on the $\mathrm{X}$-axis and the observed values on the $Y$ axis, as reported by Tedeschi (2006).

Non-rejection of the nil hypotheses was concluded by the similarity among predicted and observed values. The comparative assessment of the prediction efficiency among the systems was realized by assessing and by the partitioning of the mean squared error of prediction (MSPE) according to protocols reported by Kobayashi \& Salam (2000).

\section{Results and Discussion}

Red Norte and Nellore animals presented 1.81 and $1.43 \mathrm{~kg} /$ day daily weight gain (DWG), respectively, in the 84 days of the experiment (Table 3). The superiority of the Red Norte genetic group was justified by the heterosis resulting from the crossings and from the presence of European breeds in their composition which have high growth rates. The theory by Euclides Filho et al. (2002) which supports the existence of heterotic effect defines that there will only be heterosis when there is difference in genetic frequency 
among the breeds involved in the cross and the effect of dominance among alleles is not zero. These authors also observed greater daily weight gains in crossed $1 / 2$ Caracu $1 / 4$ Angus $1 / 4$ Nelore $(1.25 \mathrm{~kg} /$ day) and $1 / 2$ Caracu $1 / 4$ Simental $1 / 4$ Nelore $(1.15 \mathrm{~kg} /$ day), compared to Nellore animals $(1.00 \mathrm{~kg} /$ day) submitted to a diet with a 70:30 roughage: concentrate ratio. Goulart et al. (2008), in an experiment with four genetic groups (Aberdeen Angus $\times$ Nellore, Simental $\times$ Nellore, Canchim $\times$ Nellore and pure Nellore), observed superior weight gain early in the Aberdeen Angus $\times$ Nellore group, than when submitted to a diet with $40 \%$ concentrate, presented $1.70 \mathrm{~kg} /$ day daily weight gain. No difference was observed among the other genetic groups which presented an average gain of $1.50 \mathrm{~kg} / \mathrm{day}$.

Food efficiency differed $(\mathrm{P}<0.05)$ among the genetic groups: Red Norte animals presented 0.180 food efficiency and the Nellore breed 0.13 . This was because Red Norte animals can present greater weight at maturity compared to the Nellore animals, thus growth deceleration would occur later.

Significant difference was observed in the rib eye area measured by ultrasonography in the Red Norte $\left(75.41 \mathrm{~cm}^{2}\right)$ compared to the Nellore animals $\left(68.67 \mathrm{~cm}^{2}\right.$; Table 4). According to Alencar \& Packer (2005), crossbred steer tend to present greater rib eye area than pure Zebu animals.

Table 3 - Mean of the minimum squares and respective standard errors (SE) of the starting and finishing weights and the average daily gain (ADG) of Nellore and Red Norte steers finished on a feedlot

\begin{tabular}{lccccc}
\hline Variable & \multicolumn{5}{c}{ Breed } \\
\cline { 2 - 6 } & Nelore & SE & Red Norte & SE & P \\
\hline Initial weight & 361 & 6.53 & 367 & 6.28 & 0.76 \\
Final weight & 482 & 8.66 & 519 & 8.11 & $<0.01$ \\
ADG (0-28 days) & $1.39 \mathrm{a}$ & 0.102 & $1.85 \mathrm{~b}$ & 0.095 & $<0.01$ \\
ADG (0-56 days) & $1.55 \mathrm{a}$ & 0.068 & $1.88 \mathrm{~b}$ & 0.071 & $<0.01$ \\
ADG (0-84 days) & $1.43 \mathrm{a}$ & 0.050 & $1.81 \mathrm{~b}$ & 0.060 & $<0.01$ \\
\hline
\end{tabular}

Means followed by different letters on the lines differ $(\mathrm{P}<0.05)$ by $\mathrm{F}$ test.

Table 4 - Mean of the minimum squares and respective standard errors of the mean (SE) for carcass yield (CY), rib eye area (REA), fat thickness over the Biceps femoris muscle (FTBF) thickness (BT) and backfat thickness (BFT) in Nellore and Red Norte steers

\begin{tabular}{lcccc}
\hline & \multicolumn{2}{c}{ Breed } & SE & P \\
\cline { 2 - 3 } & Nelore & Red Norte & & \\
\hline Carcass yield (\%) & 57 & 53.8 & 0.4042 & 0.01 \\
Rib eye area $\left(\mathrm{cm}^{2}\right)$ & 68.67 & 75.41 & 2.110 & 0.03 \\
FTBF (mm) & 5.73 & 5.88 & 0.4617 & 0.82 \\
BFT (mm) & 4.01 & 4.14 & 0.270 & 0.73 \\
\hline
\end{tabular}

Literature indicates that when the rib eye area is larger, the carcass yields in cuts with greater commercial value will be higher. For the Red Norte group, the results obtained for rib eye area associated to the high DWG suggested that these animals were still in muscle tissue deposition phase and that they had not yet started the greater fat deposition phase because, according to the literature, they are antagonistic characteristics. According to Owens (1995), faster weight gains are related to high gain rates in protein for animals in feedlot.

Although the growth rate of the Red Norte animals was higher, both genetic groups presented minimum fat content so that harmful effects were prevented during carcass chilling. According to Lucchiari Filho (2000), the desirable subcutaneous fat thickness for good carcass conservation is $3 \mathrm{~mm}$ at least. Lack of covering fat means that the cattle carcasses become dark-colored on the external part of the muscles during chilling, damaging their appearance and shortening fibers, which decrease tenderness and depreciates the commercial value.

Results similar to those of the present experiment were obtained by Goulart et al. (2008), who did not observe differences in the backfat thickness in the Nellore, Simental $\times$ Nelore and Canchim $\times$ Nelore genetic groups and also obtained a value close to $4 \mathrm{~mm}$. Putrino et al. (2002), in an experiment with animals submitted to diet with $60 \%$ concentrate, observed $7.58 \mathrm{~mm}$ subcutaneous fat content.

Significant difference was not observed for fat thickness over the Biceps femoris muscle (FTBF) thickness (P8) among the genetic groups studied. Fat deposition occurred last in this region and advanced towards the spine (Silva et al., 2002). According to Sainz et al. (2003), fat deposition in this region is less sensitive to the characteristics of the diet compared to subcutaneous fat thickness measured between the $12^{\text {th }}$ and $13^{\text {th }}$ ribs. The animals of the Red Norte breed, when measured by ultrasonography, presented superior body weight $(\mathrm{P}<0.01)$ to the Nellore animals ( 519 and $482 \mathrm{~kg}$, respectively) and similar fat thickness, which corroborated the hypothesis that these animals were in the ascendant phase of the growth curve characterized by greater increases in muscular tissue in detriment to adipose tissue. According to Lanna (1997), protein deposition is less energetically efficient than adipose tissue deposition (efficiency in using metabolizable energy for these depositions), but it is more efficient in terms of tissue weight deposited because for each unit of protein, about three units of water are deposited in association, therefore weight deposition in the form of muscle is about four times more efficient than that of adipose tissue. 
The NRC (2000), CNCPS 5.0 and BR-CORTE systems were inaccurate and imprecise in predicting the animal performance (Table 5), which was confirmed by assessing the value of the intercept and the slope of the regression equations, which were different from zero and one, respectively, with consequent rejection of the nil hypothesis. Because the intercept and slope were different from zero and one, it was admitted that the systems were not accurate (Tedeschi, 2006). Furthermore, the coefficient of determination $\left(\mathrm{r}^{2}\right)$ was low for all the systems that indicated low precision according to (Tedeschi, 2006). Overestimation was observed for weight gain for the Nellore breed and underestimation for the Red Norte composite animals. Gesualdi Júnior et al. (2005) worked with validation of the NRC (2000) and CNCPS 5.0 systems and observed that the NRC system was not efficient in predicting the Nellore and Caracu performance but it was observed good DWG prediction by using the CNCPS 5.0 system. Lanna et al. (1994) compared prediction by the CNCPS 3.0 and NRC (1984) systems for zebu animals and observed that the daily weight gain was underestimated by both systems. Ribeiro et al. (2009) researced different zebu genetic groups and observed that neither the NRC (2000) nor the CNCPS 5.0 systems were efficient in predicting Nellore breed performance.

The inefficiency of the nutritional requirement systems in predicting the Nellore breed performance may have resulted from the fact that it is considered that zebu present energy requirements for maintenance about $10 \%$ lower than that observed for taurine animals $\left(77 \mathrm{kcal} / \mathrm{BW}^{0.75}\right)$. Thus, under the conditions of the present experiment, Nellore breed would have greater energy available for the productive functions because the energy intake was similar among the genetic groups (Machado Neto et al., 2010), resulting in greater predicted ADG when using these systems. However, the energy requirements for zebu maintenance is only slightly lesser than that reported for taurine animals (75 kcal/PV ${ }^{0.75}$ ) (Chizzotti et al., 2007). Moreover, according to Freitas et al. (2006) there are no differences in the net energy requirement for maintenance among Bos taurus, Nelore, and their crosses with Angus, Brown Swiss and Simental, in which the mean value obtained was $79 \mathrm{kcal} / \mathrm{BW}^{0.75}$. Ferrell \& Jenkins (1998) and Tedeschi et al. (2002) also stated that the energy requirements for zebu maintenance were not less than those of taurine animals. Disagreeing from these authors and the NRC (2000), Ledger (1977), Ledger \& Sayers (1977) and Leal de Araújo et al. (1998) stated that the maintenance energy requirement for zebu was $5 \%$ greater than that of Taurine animals.
The lack of accuracy and precision in predicting weight gain for Nellore animals may also be the result of the fact that the weight and body composition at maturity for these animals is not yet a consensus among researchers. Obtaining this information may improve the energy requirement estimates for weight gain and consequently the predictions for this trait. According to Valadares Filho et al. (2009), fat content in the weight at maturity should also be defined for this breed because Nellore cattle will probably not present $28 \%$ body fat content in the body weight at maturity. Furthermore, prediction errors can result from the difficulty of the requirement models in describing the compensatory gain. However, by starting from the premise that the compensatory growth tends to occur in the first 50 days in feedlot (Ryan et al., 1990; Boin \& Tedeschi 1997; Hoffmann, 2009), the lack of accuracy and precision of the systems under the conditions of the present experiment should not be considered as a compensatory gain effect, especially in the case of the Red Norte breed, in which the weight gain was underestimated by the systems.

Similar to the Nellore breed, there is no information in the literature on weight at maturity and fat content at this weight in composite animals such as Red Norte. Thus, the low accuracy and precision in the systems (Table 7) in predicting the performance of these animals might be the result of these factors.

In addition, protein and carbohydrate fractions used in the nutritional requirement systems were not determined in the laboratory but obtained from the Tabela Brasileira de Composição de Alimentos para Bovinos (Valadares Filho et al., 2006b) a fact that might have contributed to the results obtained (Figure 1; Table 5).

Similar to the Nellore animals, the nutritional requirement systems were not efficient in predicting the performance of the Red Norte breed (Figure 2; Table 6). This shows the mean, the upper and lower limits of the average daily weight gain values observed and predicted by the systems and the coefficient of variation.

Table 5 - Regression of the daily weight gain values (DWG) observed and predicted by the NRC (2000), CNCPS 5.0 and BR-CORTE systems and respective standard errors of the mean (SE) for the Nellore breed

\begin{tabular}{lccccc}
\hline System & $\mathrm{r}^{2} \mathrm{a}$ & $\mathrm{a}$ & $\mathrm{b}$ & $\mathrm{SE}$ & $\mathrm{P}$ \\
\hline NRC (2000) & 0.2392 & 2.427 & -0.6101 & 0.394 & $<0.01$ \\
CNCPS & 0.2880 & 2.720 & -0.7291 & 0.461 & $<0.01$ \\
BR-CORTE & 0.1280 & 2.220 & -0.3808 & 0.443 & $<0.01$ \\
\hline a = intercept; b = inclination of the regression equation. & &
\end{tabular}



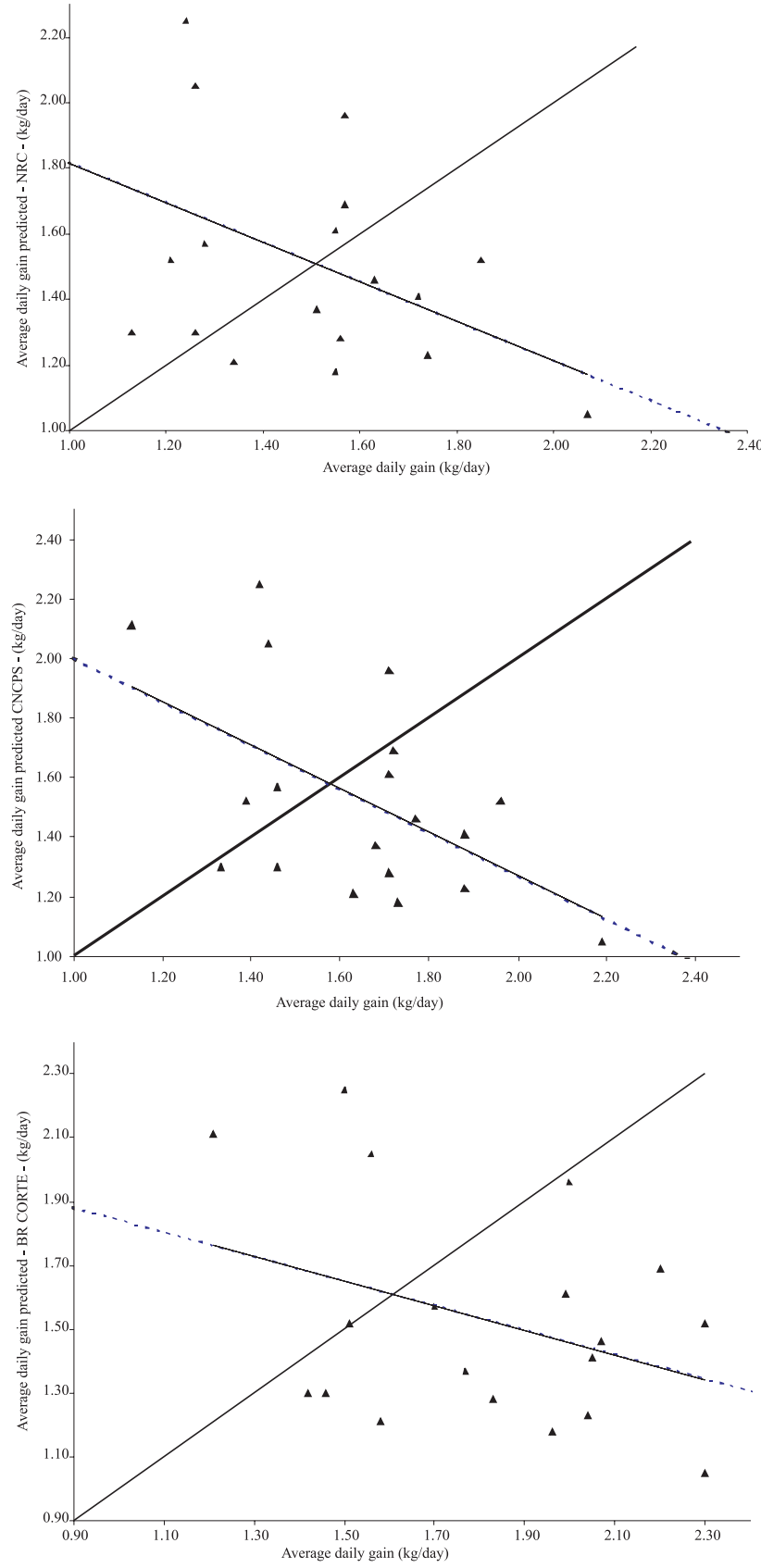

Continuous line $=$ ideal ratio $(\mathrm{X}=\mathrm{Y})$; dotted line $=$ linear regression .

Figure 1 - Regression analyses to assess the average daily weight gain predictions by the NRC (2000), CNCPS 5.0 and BR-CORTE systems for the Nellore breed.

Table 6 - Regression of the average daily gain (ADG) values observed and predicted by the NRC (2000), CNCPS 5.0 and BR-CORTE systems and respective standard errors (SE) in the mean (SE) for the Red Norte breed

\begin{tabular}{lccccc}
\hline System & $\mathrm{r}^{2} \mathrm{a}$ & $\mathrm{a}$ & $\mathrm{b}$ & $\mathrm{SE}$ & $\mathrm{P}$ \\
\hline NRC (2000) & 0.0114 & 1.671 & 0.1405 & 0.430 & $<0.01$ \\
CNCPS & 0.0080 & 1.811 & 0.0400 & 0.503 & $<0.01$ \\
BR-CORTE & 0.0683 & 1.321 & 0.3200 & 0.469 & $<0.01$ \\
\hline
\end{tabular}

$\mathrm{a}=$ intercept; $\mathrm{b}=$ inclination of regression equation.
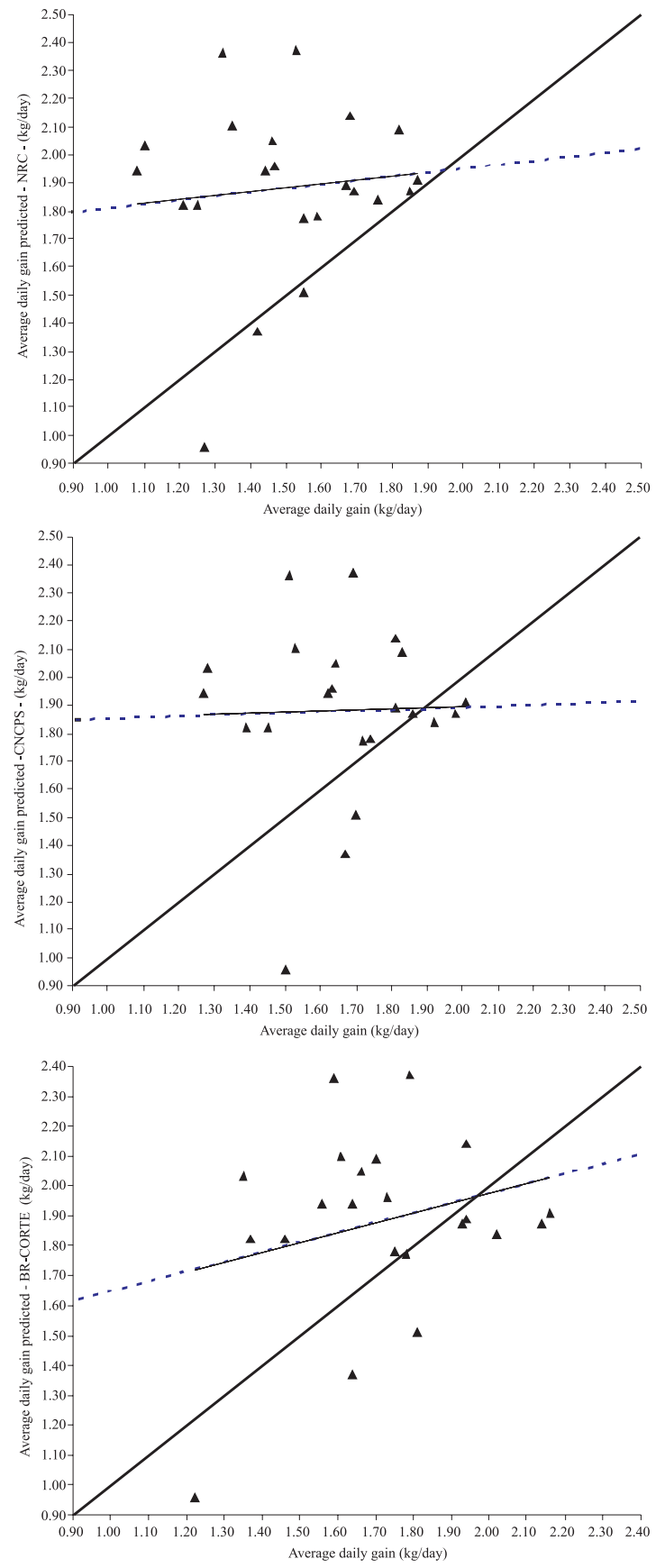

Continuous line $=$ ideal ratio $(\mathrm{Y}=\mathrm{X})$; dotted line $=$ linear regression

Figure 2 - Regression analyses to assess the average daily weight gain predictions by the NRC (2000), CNCPS 5.0 and BR-CORTE systems for the Red Norte breed.

According to Kobayashi \& Salam (2000), the regression analysis technique is limited in comparing values observed and predicted by mathematical models because by using this technique it is assumed that there is a linear relationship among the predicted and observed values which is not always true because there may be a curvilinear relationship among the predicted and observed values. Furthermore, 
according to Tedeschi (2006), some assumptions should be considered when using regression: the values dispersed on the $\mathrm{X}$ axis should be known without error, which is only possible when the model is deterministic and the predicted values are plotted on the $\mathrm{X}$ axis; the $\mathrm{Y}$ axis values should be independent, random and homocedastic and the errors should be independent with normal distribution. Besides, according to Kobayashi \& Salam (2000) and Analla (1998), this type of assessment should be based on analysis of the mean square of the predicted error (MSPE). Thus, in addition to the regression analysis technique to assess the models, the MSPE and its components were also calculated (Table 8).

Despite of the low accuracy and precision of all the models studied according to the MSEP analysis, the NRC (2000) and CNCPS 5.0 systems were the least efficient in predicting the performance for the Nellore breed because they presented low MSEP values and small systematic deviations compared to the BR-CORTE system. However, for the Red Norte breed, it was observed that the least efficient system was the BR-CORTE system.

Table 7 - Average daily gain (ADG) observed in the first two experimental periods and the values predicted by the NRC (2000), CNCPS 5.0 and BR-CORTE equations for Nellore and Red Norte steer

\begin{tabular}{|c|c|c|c|c|c|c|c|c|c|c|c|c|c|c|c|c|}
\hline \multirow[b]{2}{*}{ Breed } & \multicolumn{4}{|c|}{ ADG observed } & \multicolumn{4}{|c|}{ ADG predicted NRC (2000) } & \multicolumn{4}{|c|}{ ADG predicted CNCPS } & \multicolumn{4}{|c|}{ ADG predicted BR-CORTE } \\
\hline & Least & Mean & Highest & $\overline{\mathrm{CV}}$ & Least & Mean & Highest & $\mathrm{CV}$ & Least & Mean & Highest & $\mathrm{CV}$ & Least & Mean & Highest & $\mathrm{CV}$ \\
\hline Nelore & 1.05 & 1.3 & 2.5 & 22.4 & 1.1 & 1.53 & 2.10 & 17.73 & 1.19 & 1.70 & 2.22 & 14.89 & 1.26 & 1.82 & 2.35 & 16.8 \\
\hline R.Norte & 0.96 & 1.8 & 2.7 & 17.3 & 1.8 & 1.50 & 1.85 & 14.29 & 1.27 & 1.66 & 2.01 & 11.11 & 1.22 & 1.72 & 2.16 & 13.19 \\
\hline
\end{tabular}

Table 8 - Analyses of the mean square error of the prediction (MSEP) and its partitioning

\begin{tabular}{|c|c|c|c|c|c|c|}
\hline & & Nelore & & & Red Norte & \\
\hline & NRC & CNCPS & BR - CORTE & NRC & CNCPS & BR-CORTE \\
\hline MSEP & 0.27196 & 0.27068 & 0.36276 & 0.27490 & 0.17526 & 0.13640 \\
\hline Variance of MSEP & 0.17412 & 0.12653 & 0.14854 & 0.10326 & 0.04278 & 0.02345 \\
\hline Std deviation of MSEP & 0.41727 & 0.35570 & 0.38541 & 0.32134 & 0.20682 & 0.15315 \\
\hline Coefficient of variation of MSEP & 153.43 & 131.41 & 106.24 & 116.89 & 118.00 & 112.27 \\
\hline Root square of MSEP & 0.52150 & 0.52027 & 0.60230 & 0.52431 & 0.41864 & 0.36932 \\
\hline MSEP decomposition & & & & & & \\
\hline Mean bias & 0.00341 & 0.01257 & 0.07988 & 0.14788 & 0.04820 & 0.02678 \\
\hline Systematic bias & 0.01081 & 0.00440 & 0.03748 & 0.03845 & 0.03754 & 0.02615 \\
\hline Random error & 0.08418 & 0.07876 & 0.09647 & 0.08857 & 0,08952 & 0,08347 \\
\hline
\end{tabular}

\section{Conclusions}

Animals of the Red Norte breed present greater daily weight grain than those of the Nellore breed when kept in a feedlot. Red Norte breed has a carcass with superior rib eye area to that of the Nellore breed. The NRC (2000), CNCPS 5.0 and BR-CORTE systems are not efficient in predicting the performance of Nellore and Red Norte animals.

\section{References}

ALENCAR, M.M. Utilização de cruzamentos industriais na pecuária de corte tropical. In: SANTOS, F.A.P.; MOURA, J.C.; FARIA, V.P. (Orgs.). Pecuária de corte intensiva nos trópicos. Piracicaba: FEALQ, 2004. p.149-170.

ALENCAR, M.M.; PACKER, I.U. Competitividade depende do cruzamento de raças. Revista Visão Agrícola, v.3, p.55-58, 2005.

ANALLA, M. Model validation through the linear regression fit to actual versus predicted values. Agricultural Systems, v.57, p.115-119, 1998.
BOIN, C.; TEDESCHI, L.O. Sistemas intensivos de produção de carne bovina: II. Crescimento e acabamento. In: SIMPÓSIO SOBRE PECUÁRIA DE CORTE, 4., Piracicaba, 1996. Anais.. Piracicaba: FEALQ, 1997. p.205-228.

CASALI, A.O.; DETMANN, E.; VALADARES FILHO, S.C. et al. Influência do tempo de incubação e do tamanho de partículas sobre os teores de compostos indigestíveis em alimentos e fezes bovinas obtidos por procedimentos in situ. Revista Brasileira de Zootecnia, v.37, p.335-342, 2008.

CHIZZOTTI, M.L.; VALADARES FILHO, S.C.; TEDESCHI, L.O. et al. Energy and protein requirements for growth and maintenance of F1 Nellore x Red Angus bulls, steers, and heifers. Journal of Animal Science, v.85, p.1971-1981, 2007.

EUCLIDES FILHO, K.; FIGUEREDO, G.R.; EUCLIDES, V.P.B. Eficiência bionutricional de animais da raça Nelore e seus mestiços com Caracu, Angus e Simental. Revista Brasileira de Zootecnia, v.31, p.331-334, 2002.

FERRELL, C.L.; JENKINS, T.G. Body composition and energy utilization by steers of diverse genotypes fed a high-concentrate diet during the finishing period: II. Angus, Boran, Brahman, Hereford, and Tuli sires. Journal of Animal Science, v.76, p.647-657, 1998.

FOX, D.G.; SNIFFEN, C.J.; O'CONNOR, J.D. et al. A net carbohydrate and protein system for evaluating cattle diets. III. Cattle requirements and diets adequacy. Journal of Animal Science, v.70, n.11, p.3578-3596, 1992. 
GESUALDI JÚNIOR, A.; QUEIROZ, A.C.; RESENDE, F.D et al. Validação dos sistemas VIÇOSA, CNCPS e NRC para formulação de dietas para bovinos Nelore e Caracu, não-castrados, selecionados em condições brasileiras Revista Brasileira de Zootecnia, v.34, p.997-1005, 2005.

GOULART, R.S.; ALENCAR, M.M.; POTT, E.B. et al. Composição corporal e exigências líquidas de proteína e energia de bovinos de quatro grupos genéticos terminados em confinamento. Revista Brasileira de Zootecnia, v.37, n.5, p.926-935, 2008.

HOFFMANN, B. Parametrização e validação de um modelo de estimativas das exigências e do desempenho de gado de corte. 2009. 113f. Tese (Doutorado em Agronomia) - Escola Superior de Agricultura “Luiz de Queiroz”, Universidade de São Paulo, Piracicaba.

KOBAYASHI, K.; SALAM, M.U. Comparing simulated and measured values using mean squared deviation and its components. Agronomy Journal, v.92, p.345-352, 2000.

LANNA, D.P.D. Fatores condicionantes e predisponentes da puberdade e da idade de abate. In: PEIXOTO, A.M.; MOURA, J.C.; FARIA, V.P. (Orgs.). Produção do novilho de corte. Piracicaba: FEALQ, 1997. p.41-78.

LANNA, D.P.D.; ALMEIDA, R. A terminação de bovinos em confinamento. Visão Agrícola, v.3, p.55-58, 2005.

LEAL DE ARAÚJO, G.G.; VALADARES FILHO, S.C.; COELHO DA SILVA, J.F. et al. Efficiency of metabolizable energy utilization for maintenance and weight gain and requirements for metabolizable energy and total digestible nutrients of calves fed rations with different forage levels. Revista Brasileira de Zootecnia, v.27, p.1031-1036, 1998.

LEDGER, H.P. The utilization of dietary energy by steers during periods of restricted food intake and subsequent realimentation. 2. The comparative energy requirements of penned and exercised steers for long term maintenance at constant live weight. Journal of Agricultural Science, v.88, p.27-33, 1977.

LEDGER, H.P.; SAYERS, A.R. The utilization of dietary energy by steers during periods of restricted food intake and subsequent realimentation. 1 . The effect of time on the maintenance requirements of steers held at constant live weights. Journal of Agricultural Science, v.88, p.11-26, 1977.

LUCHIARI FILHO, A. Pecuária da carne bovina. São Paulo: A. Luchiari Filho, 2000. 134p

MACHADO NETO, O.R.; LADEIRA, M.M.; GONÇALVES, T.M. et al. Feed intake and prediction assessments using the NRC, CNCPS and BR-CORTE systems in Nellore and Red Norte steers finished in feedlot. Revista Brasileira de Zootecnia, v.39, p.394-401, 2010.

MAYER, D.G.; STUART, M.A.; SWAIN, A.J. Regression of realworld data on model output: an appropriate overall test of validity. Agricultural Systems, v.45, p.93-104, 1994.

NATIONAL RESEARCH COUNCIL - NRC. Nutrients requeriments of beef cattle. 7.ed. Washington, D.C., 2000. 244p.

NATIONAL RESEARCH COUNCIL - NRC. Nutrient requeriments of dairy cattle. 7.rev.ed. Washington, D.C.: 2001. 381p.

OWENS, F.N.; GILL, D.R. Review of some aspects of growth and development of feedlot catle. Journal of Animal Science, v.73, p.3152-3172, 1995.
PUTRINO, S.M.; LEME, P.R.; SILVA, S.L. et al. Desempenho de tourinhos Brangus e Nelore alimentados com diferentes proporções de concentrado. In: REUNIÃO ANUAL DA SOCIEDADE BRASILEIRA DE ZOOTECNIA, 39., 2002, Fortaleza. Anais.. Fortaleza: Sociedade Brasileira de Zootecnia, 2002. (CD-ROM).

RESTLE, J.; QUADROS, A.R.; VAZ, F.N. Terminação em confinamento de novilhos de diferentes genótipos de Hereford x Nelore. Revista Brasileira de Zootecnia, v.29, n.1, p.125-130, 2000.

RIBEIRO, J.S.; LADEIRA, M.M.; GONÇALVES, T.M. et al. Predição de desempenho com o uso de sistemas de exigências nutricionais e características de carcaça de tourinhos zebuínos. Pesquisa Agropecuária Brasileira, v.44, p.1724-1730, 2009.

RYAN, W.J. Compensatory growth in the cattle and sheep. Nutrition Abstracts and Reviews (Series B), v.6, n.9, p.653-664, 1990.

SAINZ, R.D.; ARAUJO, F.R.C.; MANICARDI, F. et al. Melhoramento genético da carcaça em gado zebuíno. In: SEMINÁRIO NACIONAL DE CRIADORES E PESQUISADORES, 12., 2003, Ribeirão Preto. Anais... Ribeirão Preto, 2003. p.1-12.

SALIBA, E.O. Uso de indicadores: passado, presente e futuro. In: TELECONFERÊNCIA SOBRE O USO DE INDICADORES EM NUTRIÇÃO ANIMAL, 1., 2005, Belo Horizonte. Anais... Belo Horizonte, 2005.

SIQUEIRA, G.R.; BERNARDES, T.F.; SIGNORETTI, R.D. et al. A produção de volumosos conservados como componente do sistema de produção de bovinos de corte. In: SIMPÓSIO DE PECUÁRIA DE CORTE, 5., 2007, Lavras. Anais... Lavras: SIMPEC, 2007. p.165-228.

SILVA, F.F.; VALADARES FILHO, S.C.; ÍTAVO, L.C.V .et al. Consumo, desempenho, características de carcaça e biometria do trato gastrintestinal e dos órgãos internos de novilhos Nelore recebendo dietas com diferentes níveis de concentrado e proteína. Revista Brasileira de Zootecnia, v.31, p.1849-1864, 2002.

SILVA, D.J.; QUEIROZ, A.C. Análises de alimentos (métodos químicos e biológicos). 3.ed. Viçosa, MG: Editora UFV, 2002. 235p.

SNIFFEN, C.J.; O’CONNOR, J.D.; VAN SOEST, P.J. et al. A net carbohydrate and protein system for evaluating cattle diets: II. carbohydrate and protein availability. Journal of Animal Science, v.70, p.3562-3577, 1992.

STATISTICAL ANALYSES SYSTEM - SAS. SAS/STAT user's guide: statistics. 4.ed. Cary: 1999. v.2, 943p.

TEDESCHI, L.O.; BOIN, C.; FOX, D.G. et al. Energy requirement for maintenance and growth of Nellore bulls and steers fed high-forage diets. Journal of Animal Science, v.80, p.1671-1682, 2002.

TEDESCHI, L.O. Assessment of the adequacy of mathematical models. Agricultural Systems, v.89, p.255-247, 2006.

VALADARES FILHO, S.C.; AZEVEDO, J.A.G.; PINA, D.S. et al. Desenvolvimento de equações para predizer o consumo de matéria seca de bovinos Nelore e mestiços. In: ZOOTEC CONGRESSO BRASILEIRO DE ZOOTECNIA, 1., 2006, Recife. Anais... Recife, 2006a. v.1, p.1-26.

VALADARES FILHO, S.C.; PAULINO, P.V.R.; MAGALHÃES, K.A. Exigências nutricionais de zebuínos e tabelas de composição de alimentos BR-CORTE. Viçosa, MG: UFV, DZO, 2006b. $142 \mathrm{p}$. 